\title{
Single-nucleotide polymorphisms of APE1 associated with risk and prognosis of vitiligo in a Han Chinese population
}

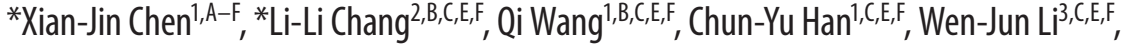 \\ Fu-Jun Tian ${ }^{4, A-F}$, Li-Qian Liu ${ }^{4, C, E, F}$ \\ ${ }^{1}$ Department of Dermatology, Affiliated Yantai Yuhuangding Hospital of Qingdao University Medical College, Yantai, China \\ ${ }^{2}$ Department of Intensive Care Unit, Affiliated Yantai Yuhuangding Hospital of Qingdao University Medical College, Yantai, China \\ ${ }^{3}$ Yantai Institute of Coastal Zone Research, Chinese Academy of Sciences, China \\ ${ }^{4}$ Department of Dermatology, Linyi People's Hospital, China \\ A - research concept and design; B - collection and/or assembly of data; C - data analysis and interpretation; \\ $D$ - writing the article; $E$ - critical revision of the article; $F$ - final approval of the article
}

\section{Address for correspondence \\ Xian-Jin Chen}

E-mail: chenxianjin_yt@126.com

Funding sources

None declared

Conflict of interest

None declared

Acknowledgements

The authors wish to thank the reviewers for their comments on this manuscript.

${ }^{*}$ The first two authors contributed equally to this work.

Received on November 13, 2015

Revised on March 16, 2016

Accepted on January 9, 2017

Published online on August 19, 2019

Cite as

Chen XJ, Chang L-L, Wang Q, et al. Single-nucleotide polymorphisms of APE1 associated with risk and prognosis of vitiligo in a Han Chinese population. Adv Clin Exp Med. 2019;28(9):1249-1255. doi:10.17219/acem/68364

DOI

10.17219/acem/68364

\section{Copyright}

Copyright by Author(s)

This is an article distributed under the terms of the

Creative Commons Attribution Non-Commercial License

(http://creativecommons.org/licenses/by-nc-nd/4.0/)

\section{Abstract}

Background. The single-nucleotide polymorphisms (SNPS) of apurinic/apyrimidinicendonuclease 1 (APE1), which has been implicated in cancers and the DNA base excision repair (BER) process, have not been thoroughly investigated in association with the risks of oxidative stress-related vitiligo.

Objectives. The aim of this study is to investigate associations between APE1 single-nucleotide polymorphisms 141T $>G$ and 1349T $>G$ and risk and prognosis of vitiligo.

Material and methods. From June 2013 to June 2015, a total of 460 vitiligo patients were randomly recruited as a case group; 200 of these patients received narrow bound ultraviolet B (NB-UVB) treatment. Meanwhile, 460 healthy controls were included as a control group. Polymerase chain reaction-restriction fragment length polymorphism (PCR-RFLP) was performed to explore the distribution frequencies of genotypes.

Results. Significant differences were detected between the case group and the control group in the frequencies of the 141T $>G$ and 1349T $>G$ genotypes. At 141T $>G$, compared with patients carrying the $T G+G G$ genotype, male patients carrying the TT genotype aged more than 20 years with active non-segmental vitiligo, without a family history of vitiligo or other autoimmune diseases, exhibited an increased risk of vitligo. Binary logistic regression analysis demonstrated that the TT genotype at 141T $>G$ and the non-TT genotype at 1349T $>G$ were independent risk factors for vitiligo development. At 1349T $>G$, compared with patients carrying the $\mathrm{TT}$ genotype, male patients carrying the $\mathrm{TG}+\mathrm{GG}$ genotype aged more than 20 years with active non-segmental vitiligo, without a family history of vitiligo or other autoimmune diseases, exhibited an increased risk of vitiligo. Moreover, patients carrying 141TG + GG or 1349 TT genotypes had better photochromic effects, lower cumulative radiation doses, shorter treatment times, and earlier first photochromic times.

Key words: vitiligo, APE1, 141T >G, Asp148Glu, risk of vitiligo 


\section{Background}

Vitiligo is a depigmentation skin disorder characterized by the destruction of melanocytes, resulting in the presence of noticeable pale milk-white areas of depigmented skin. ${ }^{1,2}$ The incidence of vitiligo varies from region to region, and it is estimated that the global prevalence is less than $1 \%$ in most populations. ${ }^{3}$ Vitiligo may occur at any time, with the most prevalent onset of the disease estimated at around 24 years. ${ }^{4}$ Among all the therapies for vitiligo, including topical steroids, calcineurin inhibitors and phototherapy, narrow band ultraviolet $B$ (NB-UVB) phototherapy is found to be the most effective treatment. ${ }^{5-7}$

Patients with vitiligo have a very high risk of recurrences of segmental vitiligo. ${ }^{8,9}$ Though not entirely explained, the pathogenesis of vitiligo is commonly believed to be related to autoimmune and genetic factors, and to oxidative stress. ${ }^{10}$ Melanin synthesis is induced by oxidation reactions and superoxide anion and hydrogen peroxide $\left(\mathrm{H}_{2} \mathrm{O}_{2}\right)$ generation. ${ }^{11}$ However, over-accumulation of $\mathrm{H}_{2} \mathrm{O}_{2}$ could lead to oxidative damage and therefore bring about white spots and finally vitiligo. ${ }^{12}$ In this context, oxidative stress regulation may be a useful lever in melanin synthesis. As the name suggests, DNA base excision repair (BER) is a process repairing base damage, including single-strand breaks, non-bulky adducts, oxidative DNA damage, alkylation adducts, and damage induced by ionizing radiation. ${ }^{13}$ Evidence has shown that the induction of oxidative damage and expression of several BER genes are significantly increased in melanocytes. ${ }^{14}$ The apurinic/apyrimidinic endonuclease ( $A P E 1)$ gene is the most important gene reported in close association with oxidative-stress-related disorders. ${ }^{15,16}$ In addition, $A P E 1$ is also known as redox effector factor 1 (Ref-1), and participates in the regulation of reoxidation and transcription. ${ }^{17}$ Taking all this into account, the authors propose the hypothesis that $A P E 1$ may be involved in the development of vitiligo.

The aim of the current study, which included 460 patients with vitiligo and 460 healthy controls, was to investigate any association between APE1 SNPs $141 \mathrm{~T}>\mathrm{G}$ and $1349 \mathrm{~T}>\mathrm{G}$ and the risk of vitiligo. In addition, $200 \mathrm{pa}-$ tients who received NB-UVB treatments were followed up in order to observe the influence of $A P E 1$ polymorphisms on the prognosis in vitiligo.

\section{Material and methods}

\section{Ethical statement}

The study design was reviewed and approved by the ethics committee of the Affiliated Yantai Yuhuangding Hospital (Yantai, China). All the subjects signed written informed consent to undergo diagnostic and therapeutic procedures at the time of hospitalization. All the procedures in this study were in compliance with the Declaration of Helsinki. ${ }^{18}$

\section{Subjects}

From June 2013 to June 2015, a total of 460 patients diagnosed with vitiligo at the Affiliated Yantai Yuhuangding Hospital were randomly recruited as the case group in the study; among them, 200 received NB-UVB treatment. The diagnosis of vitiligo was confirmed based on three-dimensional computed tomography $(\mathrm{CT})$ of the skin with commercially available reflectance confocal microscopy (Vivascope 1500; Lucid Inc., Rochester, USA) and the diagnostic criteria of vitiligo. ${ }^{19}$ In patients with vitiligo, as presented in the $\mathrm{CT}$ image, the pigment rings at the dermo-epidermal junction totally disappeared in the lesion areas and appeared half-ring-shaped or fanshaped in the surrounding non-lesion areas. The case group consisted of 231 males and 229 females with a mean age of $28.6 \pm 13.9$ years. Only Han Chinese subjects were included in the current study to avoid genotype frequency variations among ethnic groups. The study's exclusion criteria included melanoma, dermatoma or other disease that may result in hypopigmentation or depigmentation of the skin and mucosa, including amelanotic nevus, pityriasis simplex and acquired pigment loss. The subjects' vitiligo was classified into stable stage and active stage, based on whether the leukoplakia had spread within the previous 6 months, whether the pigment loss was worsening and whether new leukoplakia was appearing. Based on the spreading of the leukoplakia, the vitiligo cases were grouped into non-segmental vitiligo and segmental vitiligo. Meanwhile, the healthy controls $(n=460$, including 224 females and 236 males, with a mean age of $30.6 \pm 15.0$ ) were enrolled from among patients undergoing physical examinations in the outpatient department. The exclusion criterion for the control group was a family history of vitiligo.

\section{Data collection}

For each of the 200 vitiligo patients receiving NB-UVB treatment, the researchers recorded the clinical classifications, pigmented skin lesions, the course of the disease, cumulative exposure dosage, total treatment time, the time of initial repigmentation, and overall repigmentation. Pigmented skin lesions include lesions on the patients' faces, bodies, arms, legs, hands and/or feet. The course of the disease refers to the period from the initial depigmentation to the patient's referral to the hospital. Cumulative exposure dosages were calculated as exposure dose $\times$ exposure time. The total treatment time was recorded by month. The time of initial repigmentation is the time when repigmentation was first occurred in the skin lesions. Evaluation of the overall repigmentation was based 
on the repigmentation area or the absence of leukoplakia, i.e., improvement (a decrease in or disappearance of leukoplakia, repigmentation/skin lesions $\geq 50 \%$ ) or no improvement (reappearance of or increase in leukoplakia, repigmentation/skin lesions $<50 \%){ }^{20}$

\section{APE1 SNP detection}

Fasting venous blood $(5 \mathrm{~mL})$ drawn from the forearm of each subject was placed in EDTA collecting tubes. The blood samples were centrifuged at 2,700 rpm for $10 \mathrm{~min}$ at room temperature to collect the cellular layer, then stored at $-80^{\circ} \mathrm{C}$. DNA extraction (DNA Extraction Kit; Beijing Biotech Ltd. Inc., Beijing, China) and content measurement using an ultraviolet spectrophotometer (Beckman Coulter Inc., Brea, USA) were performed. Polymerase chain reaction (PCR) amplification was conducted using synthesized primer sequences (Sangon Biotech Co. Ltd., Shanghai, China) (Table 1). The PCR reaction system includes $0.1 \mu \mathrm{g}$ of genomic DNA, $10 \mathrm{mmol} / \mathrm{L}$ of Tris$\mathrm{HCl}(\mathrm{pH}=8.0), 50 \mathrm{mmol} / \mathrm{L}$ of $\mathrm{KCl}, 2.5 \mathrm{mmol} / \mathrm{L}$ of $\mathrm{MgCl}_{2}$, $200 \mu \mathrm{mol} / \mathrm{L}$ of dNTPs, $1 \mathrm{U}$ of TaqDNA polymerase, and $0.4 \mu \mathrm{mol} / \mathrm{L}$ of oligonucleotide primer. The amplification was conducted under the conditions of initial denaturation at $94^{\circ} \mathrm{C}$ for $3 \mathrm{~min}$, followed by 37 cycles of denaturation at $94^{\circ} \mathrm{C}$ for $30 \mathrm{~s}$, annealing at $55.7^{\circ} \mathrm{C}$ for $40 \mathrm{~s}$ and extension at $72^{\circ} \mathrm{C}$ for $40 \mathrm{~s}$. The amplification was finished with final extension at $72^{\circ} \mathrm{C}$ for $10 \mathrm{~min}$. Subsequently, $8.5 \mu \mathrm{L}$ of PCR product was added with $5 \mathrm{U}$ of BgLII, $5 \mathrm{U}$ of BfaI and $1 \mu \mathrm{L}$ of $10 \times$ buffer solution (total $10 \mu \mathrm{L}$ ). Then, $10 \mu \mathrm{L}$ of the reaction system was subjected to water bath digestion for $3 \mathrm{~h}$, followed by electrophoresis with agarose gel containing $2 \%$ of ethidium bromide. The observation was performed under ultraviolet (UV) light and images were photographed for analysis.

Table 1. The primer sequences used for polymerase chain reaction amplification

\begin{tabular}{|c|c|}
\multicolumn{1}{c|}{ Position } & Sequence \\
\hline \multirow{2}{*}{$141 \mathrm{~T}>\mathrm{G}$} & Forward: 5'-CTAACTGCCAGGGACGCGA-3' $^{\prime}$ \\
\hline \multirow{2}{*}{$1349 \mathrm{~T}>\mathrm{G}$} & Reverse: 5'-ACCACTGACTTAAGATTCTAACTA-3' $^{\prime}$ \\
& Forward: 5'-ACGGCATAGGTGAGACCCTA-3' \\
\hline
\end{tabular}

\section{Statistical analysis}

Continuous data was presented as mean \pm standard deviation (SD), while categorical data was expressed as percentages. Genotype frequencies between the case group and the control group were compared using the $\chi^{2}$ test. The $\chi^{2}$ goodness-of-fit test was employed to identify whether the genotype distributions fulfilled the HardyWeinberg equilibrium. The relative risk was presented as odds ratios (OR) with 95\% confidence intervals (95\% CI). Logistic regression analysis was conducted to screen out the risk factors for vitiligo development. P-values $<0.05$ were considered statistically significant. The data analysis was conducting using SPSS v. 21.0 software (IBM Corp., Armonk, USA).

\section{Results}

\section{Clinico-pathological data}

The demographic and clinical data between the case group and the control group are presented in Table 2. The $\chi^{2}$ test found no significant differences in terms of age, sex or smoking history between the case and control groups (all $\mathrm{p}>0.05$ ). Among the 460 vitiligo patients, 374 (81.3\%) were diagnosed as being in the active stage and the remaining 86 patients $(18.7 \%)$ were in the stable stage; 36 patients (7.8\%) had segmental vitiligo, while 424 (92.2\%) had vitiligo vulgaris; 72 patients $(15.7 \%)$ had a family history of vitiligo and 388 patients (84.3\%) did not; 10 patients (2.2\%) also had an autoimmune disease, while 450 patients (97.8\%) had no autoimmune disease.

Table 2. Comparisons of the clinical baseline information of the case group and control group

\begin{tabular}{|c|c|c|c|c|c|}
\hline \multirow{2}{*}{$\begin{array}{c}\text { Baseline } \\
\text { characteristics }\end{array}$} & \multicolumn{2}{|c|}{$\begin{array}{l}\text { Case group } \\
(n=460)\end{array}$} & \multicolumn{2}{|c|}{$\begin{array}{l}\text { Control group } \\
\qquad(n=460)\end{array}$} & \multirow{2}{*}{$p$-value } \\
\hline & $\mathrm{n}$ & $\%$ & $\mathrm{n}$ & $\%$ & \\
\hline $\begin{array}{l}\text { Age [years] } \\
\leq 20 \\
>20\end{array}$ & $\begin{array}{l}150 \\
310\end{array}$ & $\begin{array}{l}32.6 \\
67.4\end{array}$ & $\begin{array}{l}164 \\
296\end{array}$ & $\begin{array}{l}35.7 \\
64.3\end{array}$ & $0.37^{*}$ \\
\hline $\begin{array}{l}\text { Sex } \\
\text { female } \\
\text { male }\end{array}$ & $\begin{array}{l}229 \\
231\end{array}$ & $\begin{array}{l}49.8 \\
50.2\end{array}$ & $\begin{array}{l}224 \\
236\end{array}$ & $\begin{array}{l}48.7 \\
51.3\end{array}$ & $0.32^{*}$ \\
\hline $\begin{array}{l}\text { Smoking history } \\
\text { yes } \\
\text { no }\end{array}$ & $\begin{array}{l}256 \\
204\end{array}$ & $\begin{array}{l}55.7 \\
44.3\end{array}$ & $\begin{array}{l}260 \\
200\end{array}$ & $\begin{array}{l}56.5 \\
43.5\end{array}$ & $0.84^{*}$ \\
\hline $\begin{array}{r}\text { Disease stage } \\
\text { active stage } \\
\text { stable stage }\end{array}$ & $\begin{array}{r}374 \\
86\end{array}$ & $\begin{array}{l}81.3 \\
18.7\end{array}$ & & & \\
\hline $\begin{array}{l}\text { Clinical phenotype } \\
\text { segmental } \\
\text { non-segmental }\end{array}$ & $\begin{array}{r}36 \\
424\end{array}$ & $\begin{array}{r}7.8 \\
92.2\end{array}$ & & & \\
\hline $\begin{array}{l}\text { Family history of vitiligo } \\
\text { yes } \\
\text { no }\end{array}$ & $\begin{array}{r}72 \\
388\end{array}$ & $\begin{array}{l}15.7 \\
84.3\end{array}$ & & & \\
\hline $\begin{array}{l}\text { Autoimmune diseases } \\
\text { yes } \\
\text { no }\end{array}$ & $\begin{array}{r}10 \\
450\end{array}$ & $\begin{array}{r}2.2 \\
97.8\end{array}$ & & & \\
\hline
\end{tabular}

* two-sided $x^{2}$ test.

\section{APE1 genotype analysis}

APE1 was located in chromosome14q11.2. APE1 1349T > G (rs1130409) was a mutation of $\mathrm{T}>\mathrm{G}$ in the $5^{\text {th }}$ exon, containing the $1349 \mathrm{~T}>\mathrm{G}$ TT genotype (238bp, 403bp), 1349T > G TG genotype (165bp, 238bp, 403bp) and 1349T > G GG genotype (165bp, 403bp), while $141 \mathrm{~T}>\mathrm{G}(\mathrm{rs} 1760944)$ was 

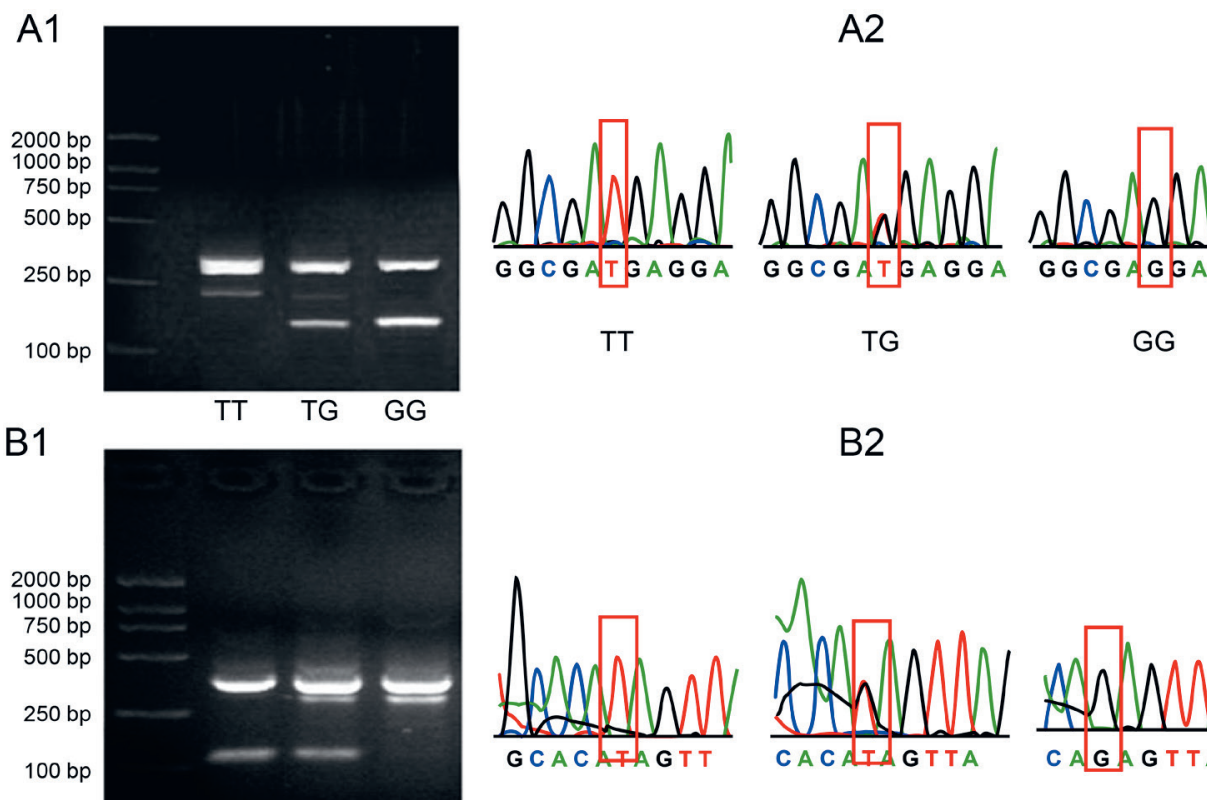

B2
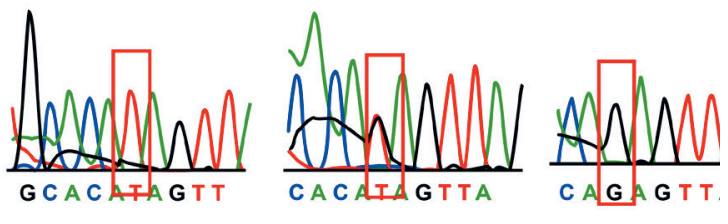

Fig. 1. The genotypes for apurinic/ apyrimidinic endonuclease 1 (APE1)1349T > G and 141T > G (A - the agarose electrophoresis results for $1349 \mathrm{~T}>\mathrm{G} ; \mathrm{B}$ - the agarose electrophoresis results for 141T > G) a mutation of $\mathrm{T}>\mathrm{G}$ in the promoter region, including the TT genotype (116bp 443bp), GG genotype (327bp, 443bp) and TG genotype (116bp, 327bp, 443bp) (Fig. 1).

\section{Genotype frequencies of APE1 141T > G and 1349T > G}

The distributions of APE1 141T > G and 1349T > G genotype frequency in both the vitiligo patients and the healthy controls fulfilled the Hardy-Weinberg equilibrium (all $\mathrm{p}>0.05)$. Taking the TT genotype of $141 \mathrm{~T}>\mathrm{G}$ as a reference, the subjects with the GG genotype and TG + GG genotype had a decreased risk of vitiligo (both $\mathrm{p}<0.05$ ). When the TT genotype of $1349 \mathrm{~T}>\mathrm{G}$ was taken as a reference, the subjects with the GG genotype and the combined TG + GG genotype had an elevated risk of vitiligo (both $\mathrm{p}<0.05$ ) (Table 3).

\section{Associations between APE1 SNPs and vitiligo phenotypes}

Using the TT genotype as reference, the $141 \mathrm{~T}>\mathrm{G}, \mathrm{TG}+$ GG genotype was associated with a decreased risk of vitiligo in the subgroups male ( $\mathrm{p}=0.035)$, more than 20 years

Table 3. Distribution of genotypes at $141 \mathrm{~T}>\mathrm{G}$ and 1349T $>\mathrm{G}$ in the case group and control group

\begin{tabular}{|c|c|c|c|c|c|c|}
\hline \multirow{2}{*}{ Genotypes } & \multicolumn{2}{|c|}{ Case group $(n=460)$} & \multicolumn{2}{|c|}{ Control group $(n=460)$} & \multirow{2}{*}{$\mathrm{p}$-value } & \multirow{2}{*}{ Adjusted OR $(95 \% \mathrm{Cl})$} \\
\hline & $\mathrm{n}$ & $\%$ & $\mathrm{n}$ & $\%$ & & \\
\hline \multicolumn{7}{|c|}{ APE1 $141 \mathrm{~T}>\mathrm{G}$} \\
\hline TT & 176 & 38.3 & 144 & 31.3 & & 1.00 (reference) \\
\hline TG & 214 & 46.5 & 218 & 47.4 & 0.140 & $0.80(0.60-1.07)$ \\
\hline GG & 70 & 15.2 & 98 & 21.3 & 0.006 & $0.58(0.40-0.85)$ \\
\hline $\mathrm{TG}+\mathrm{GG}$ & 284 & 61.7 & 316 & 68.7 & 0.032 & $0.74(0.56-0.97)$ \\
\hline \multicolumn{7}{|c|}{ Allele } \\
\hline $\mathrm{T}$ & 566 & 61.5 & 506 & 55 & & 1.00 (reference) \\
\hline G & 354 & 38.5 & 414 & 45 & 0.005 & $0.76(0.34-0.92)$ \\
\hline \multicolumn{7}{|c|}{ APE1 $1349 T>G$} \\
\hline $\mathrm{TT}$ & 127 & 27.6 & 158 & 34.3 & & 1.00 (reference) \\
\hline TG & 228 & 49.6 & 232 & 50.4 & 0.200 & $1.22(0.91-1.65)$ \\
\hline GG & 105 & 22.8 & 70 & 15.3 & 0.002 & $1.87(1.27-2.74)$ \\
\hline $\mathrm{TG}+\mathrm{GG}$ & 333 & 72.4 & 302 & 65.7 & 0.032 & $1.37(1.04-1.82)$ \\
\hline \multicolumn{7}{|c|}{ Allele } \\
\hline $\mathrm{T}$ & 482 & 52.4 & 548 & 59.6 & & 1.00 (reference) \\
\hline G & 438 & 47.6 & 372 & 40.4 & 0.002 & $1.34(1.12-1.61)$ \\
\hline
\end{tabular}

OR - odds ratios; $95 \% \mathrm{Cl}-95 \%$ confidence intervals. 
old ( $\mathrm{p}=0.019)$, non-segmental vitiligo $(\mathrm{p}=0.008)$, active vitiligo $(\mathrm{p}<0.001)$, no family history of vitiligo $(\mathrm{p}=0.017)$, and no other autoimmune diseases $(\mathrm{p}=0.049)$. When the $1349 \mathrm{~T}>$ GTT genotype was used as the reference, an elevated risk of vitiligo associated with the combined $1349 \mathrm{~T}>\mathrm{GTG}+\mathrm{GG}$ genotype was more obvious in the subgroups more than 20 years old $(p=0.045)$, male $(p=0.022)$, non-segmental vitiligo $(\mathrm{p}=0.031)$, active stage $(\mathrm{p}<0.001)$, and no family history of vitiligo $(\mathrm{p}=0.031)$ (Table 4$)$.

\section{Risk factors for vitiligo detected >G in the logistic regression analysis}

With presence of vitiligo as the dependent variable and age, sex, smoking history, the TT genotype at $141 \mathrm{~T}>\mathrm{G}$, a non-TT genotype at $141 \mathrm{~T}>\mathrm{G}$, the $\mathrm{TT}$ genotype at $1349 \mathrm{~T}>\mathrm{G}$, and a non-TT genotype at $1349 \mathrm{~T}>\mathrm{G}$ as independent variables, a binary logistic regression analysis was performed. As shown in Table 5, the TT genotype at $141 \mathrm{~T}>\mathrm{G}$ and a non-TT genotype at $1349 \mathrm{~T}>\mathrm{G}$ were independent risk factors for vitiligo development (both $\mathrm{p}<0.05$ ), while age, sex and smoking history had no significant association with vitiligo development (all $\mathrm{p}>0.05$ ).

\section{Associations between APE1 SNPs and the prognosis of vitiligo patients receiving NB-UVB treatment}

A total of 200 vitiligo patients received NB-UVB treatment, among whom 127 patients (63.5\%) had depigmentation on their faces, 110 (55.0\%) had depigmentation on their bodies, 82 patients (41.0\%) had depigmentation on their arms and legs (apart from the hands and feet), and 77 patients (38.5\%) had depigmentation on their hands and feet. Compared with subjects with the TT genotype of APE1 141T >G, patients with the TG + GG genotype had better repigmentation $\left(X^{2}=6.453, p=0.012\right)$, lower cumulative exposure dosages $\left(x^{2}=7.227, p=0.011\right)$, lower total treatment times $\left(x^{2}=6.315, p=0.015\right)$, and earlier initial repigmentation $\left(x^{2}=10.250, p=0.002\right)$. Compared

Table 4. APE1 SNPs associated with clinical phenotypes of vitiligo

\begin{tabular}{|c|c|c|c|c|}
\hline \multirow{2}{*}{ Clinical phenotype } & $141 \mathrm{~T}>\mathrm{G}$ & \multirow{2}{*}{ Adjusted OR $(95 \% \mathrm{Cl})$} & $1349 \mathrm{~T}>\mathrm{G}$ & \multirow{2}{*}{ Adjusted OR $(95 \% \mathrm{Cl})$} \\
\hline & $\mathrm{TT} / \mathrm{TG}+\mathrm{GG}$ & & $\mathrm{TT} / \mathrm{TG}+\mathrm{GG}$ & \\
\hline $\begin{array}{l}\text { Age [years] } \\
\quad \leq 20 \\
>20\end{array}$ & $\begin{array}{c}176 / 284 \\
69 / 81 \\
107 / 203\end{array}$ & $0.62(0.42-0.92)$ & $\begin{array}{l}127 / 333 \\
32 / 118 \\
95 / 215\end{array}$ & $1.63(1.03-2.58)$ \\
\hline $\begin{array}{l}\text { Sex } \\
\text { female } \\
\text { male }\end{array}$ & $\begin{array}{l}99 / 130 \\
77 / 154\end{array}$ & $0.66(0.45-0.96)$ & $\begin{array}{l}52 / 177 \\
75 / 156\end{array}$ & $1.64(1.08-2.48)$ \\
\hline $\begin{array}{l}\text { Smoking history } \\
\text { yes } \\
\text { no }\end{array}$ & $\begin{array}{l}83 / 173 \\
93 / 111\end{array}$ & & $\begin{array}{l}63 / 193 \\
64 / 140\end{array}$ & \\
\hline $\begin{array}{l}\text { Disease stage } \\
\text { active stage } \\
\text { stable stage }\end{array}$ & $\begin{array}{c}160 / 214 \\
16 / 70\end{array}$ & $0.37(0.25-0.54)$ & $\begin{array}{c}65 / 309 \\
62 / 24\end{array}$ & $12.28(7.14-21.11)$ \\
\hline $\begin{array}{l}\text { Clinical phenotype } \\
\text { segmental } \\
\text { non-segmental }\end{array}$ & $\begin{array}{c}22 / 14 \\
154 / 270\end{array}$ & 0.39 (0.19-0.78) & $\begin{array}{c}4 / 32 \\
123 / 301\end{array}$ & $3.27(1.13-9.44)$ \\
\hline $\begin{array}{l}\text { Family history of vitiligo } \\
\text { yes } \\
\text { no }\end{array}$ & $\begin{array}{c}37 / 35 \\
139 / 249\end{array}$ & $0.53(0.32-0.88)$ & $\begin{array}{c}12 / 60 \\
115 / 273\end{array}$ & $2.11(1.09-4.06)$ \\
\hline $\begin{array}{l}\text { Autoimmune diseases } \\
\text { yes } \\
\text { no }\end{array}$ & $\begin{array}{c}7 / 3 \\
169 / 281\end{array}$ & $0.26(0.07-1.01)$ & $\begin{array}{c}1 / 9 \\
126 / 324\end{array}$ & $3.50(0.44-27.91)$ \\
\hline
\end{tabular}

SNP - single-nucleotide polymorphism; OR - odds ratio; 95\% Cl: 95\% confidence interval.

Table 5. Risk factors for vitiligo development screened out using logistic regression analysis

\begin{tabular}{|l|c|c|c|c|c|}
\hline \multicolumn{1}{|c|}{ Variables } & B & S.E. & Wald & Sig. & Exp (B) \\
\hline $141 \mathrm{~T}>\mathrm{G}$ & -0.35 & 0.14 & 6.16 & 0.013 & 1.42 \\
\hline $1349 \mathrm{~T}>\mathrm{G}$ & 0.36 & 0.15 & 6.17 & 0.013 & 0.70 \\
\hline Age & -0.22 & 0.15 & 2.09 & 0.148 & 0.80 \\
\hline Sex & 0.06 & 0.14 & 0.20 & 0.654 & $1.08-1.87$ \\
\hline Smoking history & 0.08 & 0.14 & 0.36 & 0.549 & 1.09 \\
\hline
\end{tabular}

$B$ - regression coefficient; SE - standard error of regression coefficient; Wald - test statistics; Sig. - significance; Exp (B) - index of the regression coefficients; $\mathrm{Cl}$ - confidence interval. 
Table 6. Association between APEI SNPS and the prognosis of vitiligo patients receiving NB-UVB treatment

\begin{tabular}{|c|c|c|c|c|c|c|c|c|}
\hline Variables & $\begin{array}{c}141 \mathrm{~T} \\
>\mathrm{GTT}\end{array}$ & $\begin{array}{c}141 \mathrm{~T} \\
>\mathrm{G} \mathrm{TG}+\mathrm{GG}\end{array}$ & $x^{2}$ & $p$-value & $\begin{array}{l}1349 \mathrm{~T} \\
>\mathrm{G} \mathrm{TT}\end{array}$ & $\begin{array}{c}1349 \mathrm{~T} \\
>\mathrm{G} \mathrm{TG}+\mathrm{GG}\end{array}$ & $x^{2}$ & $p$-value \\
\hline $\begin{array}{l}\text { Re-pigmentation } \\
\text { re-pigmentation area } \leq 50 \% \\
\text { re-pigmentation area }>50 \%\end{array}$ & $\begin{array}{l}76 \\
27\end{array}$ & $\begin{array}{l}55 \\
42\end{array}$ & 6.453 & 0.012 & $\begin{array}{l}51 \\
43\end{array}$ & $\begin{array}{l}80 \\
26\end{array}$ & 9.924 & 0.002 \\
\hline $\begin{array}{l}\text { Cumulative exposure dosage }\left[\mathrm{J} / \mathrm{cm}^{2}\right] \\
\leq 36 \\
>36\end{array}$ & $\begin{array}{l}42 \\
61\end{array}$ & $\begin{array}{l}58 \\
39\end{array}$ & 7.227 & 0.011 & $\begin{array}{l}55 \\
39\end{array}$ & $\begin{array}{l}45 \\
61\end{array}$ & 5.138 & 0.033 \\
\hline $\begin{array}{l}\text { Total treatment time [months] } \\
\leq 6 \\
>6\end{array}$ & $\begin{array}{l}36 \\
67\end{array}$ & $\begin{array}{l}51 \\
46\end{array}$ & 6.315 & 0.015 & $\begin{array}{l}51 \\
43\end{array}$ & $\begin{array}{l}36 \\
70\end{array}$ & 8.348 & 0.004 \\
\hline $\begin{array}{l}\text { Initial time of re-pigmentation [months] } \\
\leq 1 \\
>1\end{array}$ & $\begin{array}{l}64 \\
39\end{array}$ & $\begin{array}{l}80 \\
17\end{array}$ & 10.250 & 0.002 & $\begin{array}{l}75 \\
19\end{array}$ & $\begin{array}{l}69 \\
37\end{array}$ & 5.335 & 0.027 \\
\hline
\end{tabular}

SNP - single-nucleotide polymorphism; NB-UVB - narrow band ultraviolet B.

with subjects with the combined TG + GG genotype of $A P E 11349 \mathrm{~T}>\mathrm{G}$, subjects with the 1349T > G TT genotype had better repigmentation $\left(\chi^{2}=9.924, \mathrm{p}=0.002\right)$, lower cumulative exposure dosages $\left(\chi^{2}=5.138, \mathrm{p}=0.033\right)$, reduced treatment times $\left(\chi^{2}=8.348, \mathrm{p}=0.004\right)$ and earlier initial repigmentation $\left(\chi^{2}=5.335, p=0.027\right)$ (Table 6).

\section{Discussion}

This study investigated associations of the SNPs 141T > G and $1349 \mathrm{~T}>\mathrm{G}$ in the $A P E 1$ gene with the risk of vitiligo and its prognosis. The results showed that a mutation of the SNPs at141T > G was associated with a decreased risk of vitiligo, while a mutation of $1349 \mathrm{~T}>\mathrm{G}$ confers a highly increased risk of vitiligo. Moreover, the results also showed that the combined 141TG + GG and TT genotypes at $1349 \mathrm{~T}>\mathrm{G}$ were associated with a better prognosis in vitiligo patients.

Vitiligo is a depigmentation disease usually treated by NB-UVB and characterized by irregular white spots on the face, body and/or extremities. ${ }^{21}$ It has been suggested that the loss of melanocytes from lesional skin may be a cause of the white spots, and research has shown an increase in DNA damage in the leucocytes of patients with vitiligo compared with healthy controls. ${ }^{22}$ The epidermis of vitiligo patients presents multiple signs of oxidative stress, including allantoin, a well-known indicator for reactive oxygen species (ROS)-induced stress. ${ }^{23}$ The APE1 gene, along with 8-oxoguanine glycosylase-1 (OGG1) and $\mathrm{X}$-ray repair cross-complementing-1 (XRCC1), which are significantly implicated in the BER pathway, mediates the removal of oxidatively damaged DNA and is involved in eukaryotic transcriptional regulation of gene expression. ${ }^{23,24}$ APE1 is a master regulator of ROS production and contributes greatly to the maintenance of genome stability. ${ }^{26}$ Therefore, it was reasonable to speculate that SNPs of APE1 are implicated in the occurrence and development of vitiligo by removing ROS-induced DNA damage. Several sequence variants have been identified in the $A P E 1$ gene, including an amino acid change from aspartic acid to glutamic acid (1349T $>$ G), which may be associated with hypersensitivity to ionizing radiation. ${ }^{27}$ A number of case-control studies have documented an association between the APE11349T >G SNP and susceptibilities to disease. ${ }^{15,28} 1349 \mathrm{~T}>\mathrm{G}$ GG may have altered endonuclease and DNA-binding activity, and a reduced ability to communicate with other BER proteins. ${ }^{29} \mathrm{~A}$ recent study reported that $A P E 1$ expression in the epidermal lesion and non-lesion patches of vitiligo patients is higher than in healthy controls, and showed that APE11349T > G variant genotypes confer an increased risk of vitiligo. ${ }^{23} \mathrm{~A}$ functional study revealed that individuals with the APE11349T > GGG and 1349T > GTG genotypes showed higher levels of damage, ${ }^{30}$ supporting the present study's findings that compared to $1349 \mathrm{~T}>\mathrm{G}$ TT genotype, the combined 1349T > G TG + GG genotype was associated with an increased risk of vitiligo. In addition, the present study also found that the combined 141T >G TG + GG genotype was associated with a reduced risk of vitiligo compared with the TT genotype. Similarly, a previous study showed that a variant allele $\mathrm{G}$ of APE1 141T >G was associated with an increased risk of abnormal melanocyte proliferation and then cutaneous melanoma. ${ }^{31}$ Moreover, the association was more pronounced in male vitiligo patients and those with active vitiligo, nonsegmental vitiligo, no family history of vitiligo, and an age of more than 20 years. To sum up, TT at $141 \mathrm{~T}>\mathrm{G}$ and non-TT at $1349 \mathrm{~T}>\mathrm{G}$ may be potential risk factors for vitiligo development, which was further confirmed by a logistic regression model in the present study.

This study also investigated associations between APE1 141T > G and 1349T > G SNPs and the prognosis for vitiligo, and the results showed that subjects with the combined 141TG + GG or 1349T > G TT genotype showed a better response to NB-UVB treatment, with better repigmentation, lower cumulative exposure dosages, reduced treatment times, and earlier initial repigmentation. 
It was of great importance to identify protective factors in these vitiligo prognoses, since the therapeutic options and prognoses are quite different in different individuals. ${ }^{6}$ It has been shown that a younger age, segmental vitiligo, short disease duration, and lesions located on the fleshy regions of the body may have a better chance of recovery. ${ }^{32}$

In conclusion, the present study provided evidence that $A P E 1$ SNPs are associated with the risk of vitiligo. The $\mathrm{G}$ allele at $A P E 11349 \mathrm{~T}>\mathrm{G}$ combined with the 1349T $>\mathrm{G}$ TG + GG genotype may increase the risk of vitiligo, while the combined TG + GG genotype may reduce the risk of vitiligo. In addition, the study also found that $141 \mathrm{~T}>\mathrm{G}$ and 1349T > G SNPs may be significantly associated with the prognosis of this disease. However, as an important member of the BER pathway, it is possible that APE1 functions with other genes in this pathway that are involved in the occurrence and development of vitiligo. The authors are undertaking a further study to focus on the interaction of APE1 SNPs with related molecules in vitiligo.

\section{References}

1. Toosi S, Orlow SJ, Manga P. Vitiligo-inducing phenols activate the unfolded protein response in melanocytes resulting in upregulation of IL-6 and IL-8. J Invest Dermatol. 2012;132(11):2601-2609.

2. Larhmam MA, Benjelloun M, Mahmoudi S. Vertebra identification using template matching modelmp and K-means clustering. Int J Comput Assist Radiol Surg. 2014;9(2):177-187.

3. Kruger C, Schallreuter KU. A review of the worldwide prevalence of vitiligo in children/adolescents and adults. Int J Dermatol. 2012;51(10): 1206-1212.

4. Spritz RA. Shared genetic relationships underlying generalized vitiligo and autoimmune thyroid disease. Thyroid. 2010;20(7):745-754.

5 Hossani-Madani A, Halder R. Treatment of vitiligo: Advantages and disadvantages, indications for use and outcomes. G Ital Dermatol Venereol. 2011;146(5):373-395.

6. Ezzedine K, Eleftheriadou V, Whitton M, van Geel N. Vitiligo. Lancet. 2015;386(9988):74-84.

7. Hossani-Madani AR, Halder RM. Topical treatment and combination approaches for vitiligo: New insights, new developments. G Ital Dermatol Venereol. 2010;145(1):57-78.

8. Lee DY, Kim CR, Park JH. Recurrence after epidermal grafting in segmental vitiligo. Dermatol Surg. 2011;37(11):1707-1708.

9. Workman M, Sawan K, El Amm C. Resolution and recurrence of vitiligo following excision of congenital melanocytic nevus. Pediatr Dermatol. 2013;30(6):e166-168.

10. Halder RM, Chappell JL. Vitiligo update. Semin Cutan Med Surg. 2009; 28(2):86-92.

11. Simon JD, Peles D, Wakamatsu K, Ito S. Current challenges in understanding melanogenesis: Bridging chemistry, biological control, morphology, and function. Pigment Cell Melanoma Res. 2009;22(5): 563-579.

12. Schallreuter KU, Bahadoran P, Picardo $M$, et al. Vitiligo pathogenesis: Autoimmune disease, genetic defect, excessive reactive oxygen species, calcium imbalance, or what else? Exp Dermatol. 2008;17(2): $139-140$.
13. Rahmanian $\mathrm{S}$, Taleei $\mathrm{R}$, Nikjoo $\mathrm{H}$. Radiation induced base excision repair (BER): A mechanistic mathematical approach. DNA Repair (Amst). 2014;22:89-103.

14. Mouret $S$, Forestier A, Douki T. The specificity of UVA-induced DNA damage in human melanocytes. Photochem Photobiol Sci. 2012;11(1): 155-162.

15. Bardia A, Tiwari SK, Gunisetty S, et al. Functional polymorphisms in XRCC-1 and APE-1 contribute to increased apoptosis and risk of ulcerative colitis. Inflamm Res. 2012;61(4):359-365.

16. Breton CV, Zhou W, Kile ML, et al. Susceptibility to arsenic-induced skin lesions from polymorphisms in base excision repair genes. Carcinogenesis. 2007;28(7):1520-1525.

17. Al-Attar A, Gossage L, Fareed KR, et al. Human apurinic/apyrimidinic endonuclease (APE1) is a prognostic factor in ovarian, gastro-oesophageal and pancreatico-biliary cancers. Br JCancer. 2010;102(4):704-709.

18. M PN. World Medical Association publishes the Revised Declaration of Helsinki. Natl Med J India. 2014;27(1):56.

19. Faria AR, Tarle RG, Dellatorre G, Mira MT, Castro CC. Vitiligo - Part 2 - classification, histopathology and treatment. An Bras Dermatol. 2014;89(5):784-790.

20. Hallaji Z, Ghiasi M, Eisazadeh A, Damavandi MR. Evaluation of the effect of disease duration in generalized vitiligo on its clinical response to narrowband ultraviolet B phototherapy. Photodermatol Photoimmunol Photomed. 2012;28(3):115-119.

21. Majid I, Imran S. Targeted ultraviolet B phototherapy in vitiligo: A comparison between once-weekly and twice-weekly treatment regimens. Indian J Dermatol Venereol Leprol. 2015;81(6):600-605.

22 Eskandani M, Golchai J, Pirooznia N, Hasannia S. Oxidative stress level and tyrosinase activity in vitiligo patients. Indian J Dermatol. 2010; 55(1):15-19.

23. Salem MM, Shalbaf M, Gibbons NC, Chavan B, Thornton JM, Schallreuter KU. Enhanced DNA binding capacity on up-regulated epidermal wild-type $\mathrm{p} 53$ in vitiligo by H2O2-mediated oxidation: A possible repair mechanism for DNA damage. FASEB J. 2009;23(11):3790-3807.

24. Wei C, Jian Z, Wang L, et al. Genetic variants of the APE1 gene and the risk of vitiligo in a Chinese population: A genotype-phenotype correlation study. Free Radic Biol Med. 2013;58:64-72.

25. Robertson $A B$, Klungland $A$, Rognes $T$, Leiros I. DNA repair in mammalian cells. Base excision repair: The long and short of it. Cell Mol Life Sci. 2009;66(6):981-993.

26. Tell G, Quadrifoglio F, Tiribelli C, Kelley MR. The many functions of APE1/Ref-1: Not only a DNA repair enzyme. Antioxid Redox Signal. 2009;11(3):601-620.

27. Andreassi MG, Foffa I, Manfredi S, Botto N, Cioppa A, Picano E. Genetic polymorphisms in XRCC1, OGG1, APE1 and XRCC3 DNA repair genes, ionizing radiation exposure and chromosomal DNA damage in interventional cardiologists. Mutat Res. 2009;666(1-2):57-63.

28 Li K, Li C, Gao L, et al. A functional single-nucleotide polymorphism in the catechol-O-methyltransferase gene alter vitiligo risk in a Chinese population. Arch Dermatol Res. 2009;301(9):681-687.

29. Gu D, Wang $M$, Wang $M$, Zhang $Z$, Chen J. The DNA repair gene APE1 T1349G polymorphism and cancer risk: A meta-analysis of 27 casecontrol studies. Mutagenesis. 2009;24(6):507-512.

30. Au WW, Salama SA, Sierra-Torres $\mathrm{CH}$. Functional characterization of polymorphisms in DNA repair genes using cytogenetic challenge assays. Environ Health Perspect. 2003;111(15):1843-1850.

31. Li C, Liu Z, Wang LE, Strom SS, et al. Genetic variants of the ADPRT, XRCC1 and APE1 genes and risk of cutaneous melanoma. Carcinogenesis. 2006;27(9):1894-1901.

32. Sehgal VN, Srivastava G: Vitiligo: Compendium of clinico-epidemiological features. Indian J Dermatol Venereol Leprol. 2007;73(3):149-156. 